\title{
Facile preparation of glutathione-stabilized gold nanoclusters for selective determination of chromium (III) and chromium (VI) in environmental water samples
}

\author{
Haiyan Zhang, Qian Liu, Thanh Wang, Zhaojun Yun, Guoliang Li, Jiyan Liu*, Guibin Jiang \\ State Key Laboratory of Environmental Chemistry and Ecotoxicology, Research Center for Eco-Environmental Sciences, Chinese Academy of Sciences, Beijing \\ 100085, China
}

\section{H I G H L I G H T S}

- Facile and rapid preparation of fluorescent glutathione-stabilized gold nanoclusters.

- New method for selective determination of $\mathrm{Cr}(\mathrm{III})$ and $\mathrm{Cr}(\mathrm{VI})$ using GSH-Au NCs.

- The detection method possessed simplicity, high throughput, high selectivity and sensitivity.

\section{A R T I C L E I N F O}

\section{Article history:}

Received 22 November 2012

Received in revised form 14 January 2013

Accepted 20 January 2013

Available online 28 January 2013

\section{Keywords:}

Glutathione

Gold nanoclusters

Chromium

Environmental sample

Fluorescence quenching

\section{G R A P H I C A L A B S T R A C T}

Scheme for preparation of GSH-Au NCs (a) and application in selective determination of $\mathrm{Cr}(\mathrm{III})$ and $\mathrm{Cr}(\mathrm{VI})$ (b).

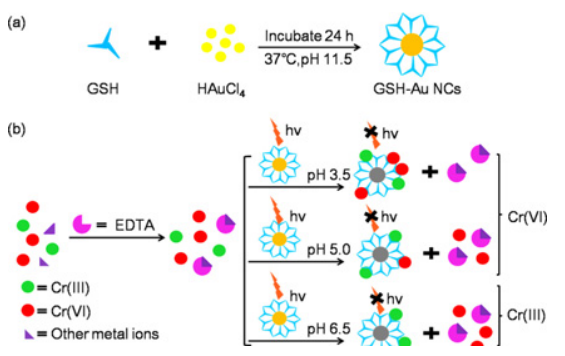

\begin{abstract}
A B S T R A C T
A novel method for selective determination of $\mathrm{Cr}(\mathrm{III})$ and $\mathrm{Cr}(\mathrm{VI})$ in environmental water samples was developed based on target-induced fluorescence quenching of glutathione-stabilized gold nanoclusters (GSH-Au NCs). Fluorescent GSH-Au NCs were synthesized by a one-step approach employing GSH as reducing/protecting reagent. It was found that $\mathrm{Cr}(\mathrm{III})$ and $\mathrm{Cr}(\mathrm{VI})$ showed $\mathrm{pH}$-dependent fluorescence quenching capabilities for GSH-Au NCs, and thus selective determination of $\mathrm{Cr}(\mathrm{III})$ and $\mathrm{Cr}(\mathrm{VI})$ could be achieved at different pHs. Addition of EDTA was able to effectively eliminate the interferences from other metal ions, leading to a good selectivity for this method. Under optimized conditions, $\mathrm{Cr}$ (III) showed a linear range of $25-3800 \mu \mathrm{g} \mathrm{L}^{-1}$ and a limit of detection (LOD) of $2.5 \mu \mathrm{g} \mathrm{L}^{-1}$. $\mathrm{The} \mathrm{Cr}(\mathrm{VI})$ ion demonstrated a linear range of $5-500 \mu \mathrm{g} \mathrm{L}^{-1}$ and LOD of $0.5 \mu \mathrm{g} \mathrm{L}^{-1}$. The run-to-run relative standard deviations $(n=5)$ for $\mathrm{Cr}(\mathrm{III})$ and $\mathrm{Cr}(\mathrm{VI})$ were $3.9 \%$ and $2.8 \%$, respectively. The recoveries of $\mathrm{Cr}(\mathrm{III})$ and $\mathrm{Cr}(\mathrm{VI})$ in environmental water samples were also satisfactory (76.3-116\%). This method, with its simplicity, low cost, high selectivity and sensitivity, could be used as a promising tool for chromium analysis in environmental water samples.
\end{abstract}

(C) 2013 Elsevier B.V. All rights reserved.

\section{Introduction}

Chromium is widely used in industrial processes such as metal smelting, leather tanning, electroplating and dyestuff, which can lead to the release of large amounts of chromium compounds into

\footnotetext{
* Corresponding author. Tel.: +86 10 62849334; fax: +861062849339.

E-mail address: liujy@rcees.ac.cn (J. Liu).
}

natural water bodies and can therefore also contaminate drinking water systems [1]. In aqueous solutions, chromium mainly exists in two valence states; namely $\mathrm{Cr}(\mathrm{III})$ and $\mathrm{Cr}(\mathrm{VI}) . \mathrm{Cr}(\mathrm{III})$ is considered to have low toxicity and is an essential trace element for mammals, while $\mathrm{Cr}(\mathrm{VI})$ is approximately 100 times more toxic and is considered a human carcinogen with adverse impact on human skin, stomachs, lung, liver and kidneys [1-3]. Therefore, measuring total chromium levels might not accurately reflect the environmental risk of chromium contamination. 
Therefore, selective determination for $\mathrm{Cr}(\mathrm{III})$ and $\mathrm{Cr}(\mathrm{VI})$ is necessary.

Over the past decades, various techniques for determination of $\mathrm{Cr}(\mathrm{III})$ and $\mathrm{Cr}(\mathrm{VI})$ have been developed, including electro-thermal atomic absorption spectroscopy (ETAAS) [4,5], spectrophotometry coupled with cloud point extraction [6] or solid phase extraction[7] or high-performance liquid chromatography[8], inductively coupled plasma optical emission spectrometry (ICP-OES) $[9,10]$, and inductively coupled plasma mass spectrometry (ICP-MS) [11]. However, most of these methods involve complex and timeconsuming sample pretreatment procedures, and can only directly detect one valence state. Additionally, instruments such as ICPOES and ICP-MS are bulky and expensive with high operating cost. Therefore, developing simple methods for selective and sensitive determination of $\mathrm{Cr}(\mathrm{III})$ and $\mathrm{Cr}(\mathrm{VI})$ is still a great challenge.

Recently, advances in synthesis and application of gold nanoclusters (Au NCs) as fluorescence probes have drawn wide attention due to their ultra-small size, large Stokes shift, low toxicity, strong fluorescence and long term stability [12]. These Au NCs have been successfully used in the determination of various heavy metals such as $\mathrm{Hg}$ (II) [13], $\mathrm{Fe}(\mathrm{III})$ [14], $\mathrm{As}$ (III) [15], $\mathrm{Cu}$ (II) [16] and $\mathrm{Pb}$ (II) [17] with advantages of being simple, rapid and economical. Glutathione (GSH) can be used as an environment friendly reducing/protecting regent for Au NCs [12] and have shown a certain affinity for chromium [18-21]. Thus it is possible to use glutathione-stabilized gold clusters (GSH-Au NCs) as a fluorescent probe for selective determination of $\mathrm{Cr}(\mathrm{III})$ and $\mathrm{Cr}(\mathrm{VI})$.

In this work, a facile one-step synthesis method of fluorescent GSH-Au NCs was developed. The as-prepared GSH-Au NCs exhibited orange-red emission at $710 \mathrm{~nm}$ with a quantum yield (QY) of 1.5\%. Speciation analysis of $\mathrm{Cr}(\mathrm{III})$ and $\mathrm{Cr}(\mathrm{VI})$ using GSH-Au NCs were achieved by varying the $\mathrm{pHs}$ of sample solutions due to $\mathrm{pH}-$ dependent fluorescence quenching capabilities of $\mathrm{Cr}(\mathrm{III})$ and $\mathrm{Cr}(\mathrm{VI})$. To the best of our knowledge, this is the first report on the application of fluorescent Au NCs for selective determination of $\mathrm{Cr}$ (III) and $\mathrm{Cr}(\mathrm{VI})$.

\section{Experimental}

\subsection{Instruments}

Fluorescence measurements and UV/vis absorption spectra were conducted with a Thermo Scientific Varioskan Flash Multimode Reader using 96-well fluorescence plates (Vantaa, Finland). The TEM images were taken by a TECNAL G2 20 electron microscope (Tokyo, Japan). The pH values were tested using a Thermo Scientific Orion* 3-Star Plus pH Benchtop Meter (Singapore).

\subsection{Materials}

Ethylenediaminetetraacetic acid (EDTA), rhodamine 6G, gold chloride trihydrate $\left(\mathrm{HAuCl}_{4} \cdot 3 \mathrm{H}_{2} \mathrm{O}\right)$ and $\mathrm{NaOH}$ were obtained from Sangon Biotech (Shanghai, China). L-Glutathione reduced ( $\geq 98.0 \%$ ) was purchased from Sigma (St. Louis, USA). 0.1 M Tris-HCl solution ( $\mathrm{pH}$ 7.4) was purchased from Solarbio (Beijing, China). All of the metal salts were purchased from Beijing Chemical Works (China). Stock solutions of $\mathrm{Cr}(\mathrm{III}), \mathrm{Cr}(\mathrm{VI}), \mathrm{Pb}(\mathrm{II}), \mathrm{Cu}(\mathrm{II}), \mathrm{Cd}(\mathrm{II}), \mathrm{Fe}(\mathrm{III})$, $\mathrm{Co}(\mathrm{II}), \mathrm{Ni}(\mathrm{II}), \mathrm{Zn}(\mathrm{II})$ and $\mathrm{Mn}$ (II) $(100 \mathrm{mM})$ were prepared in water. The standard solutions used for calibration were prepared by gradually diluting the stock solutions in water, with concentration range from 0 to $13,000 \mu \mathrm{g} \mathrm{L}^{-1}$ for $\mathrm{Cr}$ (III) and $0-1300 \mu \mathrm{g} \mathrm{L}^{-1}$ for $\mathrm{Cr}(\mathrm{VI})$. Deionized water from a Milli-Q Millipore with a resistivity of $18.2 \mathrm{M} \Omega \mathrm{cm}^{-1}$ was used. The pHs of solutions were adjusted by $\mathrm{HCl}$ or $\mathrm{NaOH}$ solutions. All chemicals and reagents used in this work were of analytical grade or higher purity without further purification.

\subsection{Preparation and purification of GSH-Au NCS}

GSH-Au NCs were synthesized by chemical reduction of $\mathrm{HAuCl}_{4}$ with glutathione. A solution of glutathione $(5 \mathrm{~mL}, 15 \mathrm{mM})$ was added to an equal volume of $10 \mathrm{mM} \mathrm{HAuCl}_{4}$. The mixture was vigorously stirred for $2 \mathrm{~min}$, followed by the addition of $1 \mathrm{M} \mathrm{NaOH}$ $(1 \mathrm{~mL})$. Then, the solution was incubated at $37^{\circ} \mathrm{C}$ under continuous stirring (ca. $200 \mathrm{rpm}$ ) for $24 \mathrm{~h}$. Excess glutathione were thereafter removed by addition of excessive methanol into the aqueous solution (the ratio between water and methanol is 1:4) and the solution was then centrifuged at 15,000 rpm for $5 \mathrm{~min}$. The precipitates were separated and finally dispersed in Tris- $\mathrm{HCl}$ solution for use.

\subsection{Detection of Cr(III) and Cr(VI) by using GSH-Au NCs at different $\mathrm{pHs}$}

The detection of $\mathrm{Cr}$ (III) and $\mathrm{Cr}(\mathrm{VI})$ using GSH-Au NCs was conducted according to the scheme shown in Fig. 1. $\mathrm{Cr}$ (III) was directly detected at $\mathrm{pH} 6.5$ where the relative fluorescence intensity of GSHAu NCs were dependent on its concentration. $\mathrm{Cr}(\mathrm{VI})$ was quantified based on the difference between relative fluorescence intensities of GSH-Au NCs at pH 3.5 and 5.0. In addition, the effects of other metal ions such as $\mathrm{Pb}(\mathrm{II}), \mathrm{Cu}(\mathrm{II}), \mathrm{Cd}(\mathrm{II}), \mathrm{Fe}(\mathrm{III}), \mathrm{Co}(\mathrm{II}), \mathrm{Ni}(\mathrm{II}), \mathrm{Zn}(\mathrm{II})$ and $\mathrm{Mn}(\mathrm{II})$ on the fluorescence intensities of GSH-Au NCs at different $\mathrm{pHs}$ were tested to evaluate the selectivity of this method.

The detailed detection procedures were as following: the standard solutions $(49 \mu \mathrm{L})$ were firstly mixed with $1 \mu \mathrm{L}$ of EDTA $(125 \mathrm{mM})$ in a 96 -well plate for $10 \mathrm{~min}$, followed by addition of $50 \mu \mathrm{L}$ of GSH-Au NCs solution. The mixed solution was allowed to reaction for $30 \mathrm{~min}$ at appropriate $\mathrm{pHs}$. Finally, the fluorescence intensity of the solutions was recorded from 550 to $800 \mathrm{~nm}$ with the excitation wavelength at $410 \mathrm{~nm}$. The whole process was carried out at room temperature.

\subsection{Feasibility test with real environmental water samples}

Tap water and effluent water samples were used to evaluate the feasibility of the method. Effluent water samples were collected from Qinghe wastewater treatment plant in Beijing. All the water samples analyzed were filtered through a Millipore cellulose membrane $(0.45 \mu \mathrm{m})$ and analyzed as described above.

\section{Results and discussion}

\subsection{Synthesis and characterization of GSH-Au NCS}

In this work, we prepared fluorescent GSH-Au NCs by a one-step method via reduction of gold salt with glutathione as both reducing and protecting agent. Molar ratios of GSH to $\mathrm{Au}, \mathrm{pH}$ and reaction time were optimized. At a given Au NCs concentration of $10 \mathrm{mM}$, the optimal concentration of GSH was found to be $15 \mathrm{mM}$, in which Au NPs showed th which Au NCs showed the strongest fluorescence (Fig. S1 A in the Supporting Information). The appropriate $\mathrm{pH}$ was 11.5 (Fig. S1B), and the reaction was allowed to proceed for $24 \mathrm{~h}$ at $37^{\circ} \mathrm{C}$ (Fig. S1C). In contrast to previously reported methods [16,22-24], this method is more rapid, which could be the effect of higher temperature. The higher $\mathrm{pH}$ could also be more beneficial to the reducing ability of glutathione, similar as the behavior of bovine serum albumin [25]. In addition, smaller nanoparticles could be formed at higher pHs due to stronger electrostatic repulsion of the carboxylate groups in GSH between adjacent ligands [26]. 
(a)

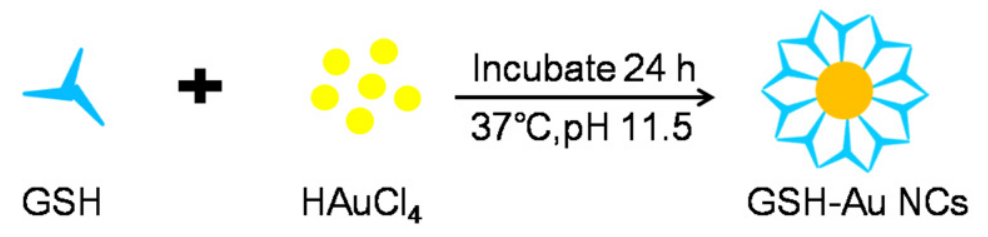

(b)

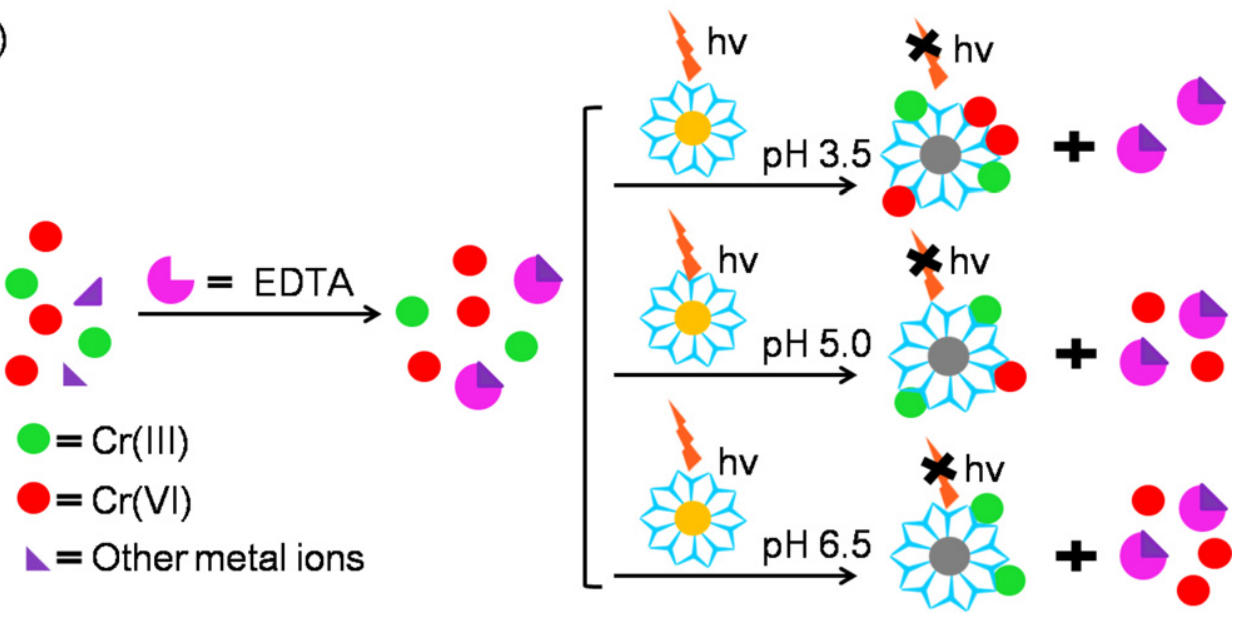

Fig. 1. Scheme for preparation of GSH-Au NCs and application in selective determination of $\mathrm{Cr}(\mathrm{III})$ and $\mathrm{Cr}(\mathrm{VI})$.

A

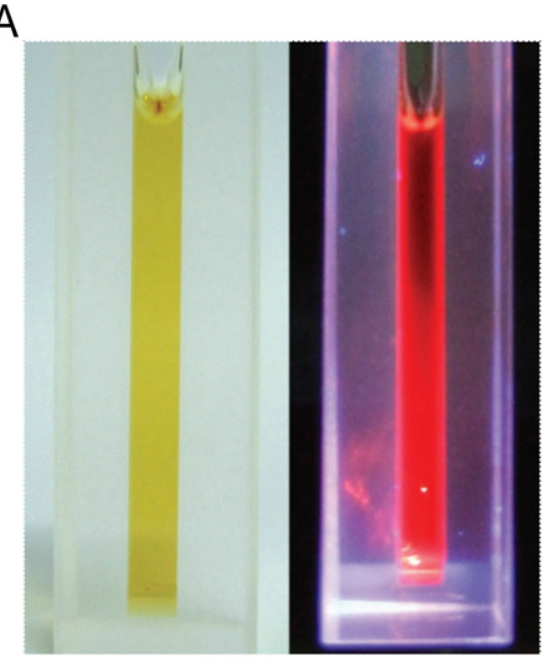

B

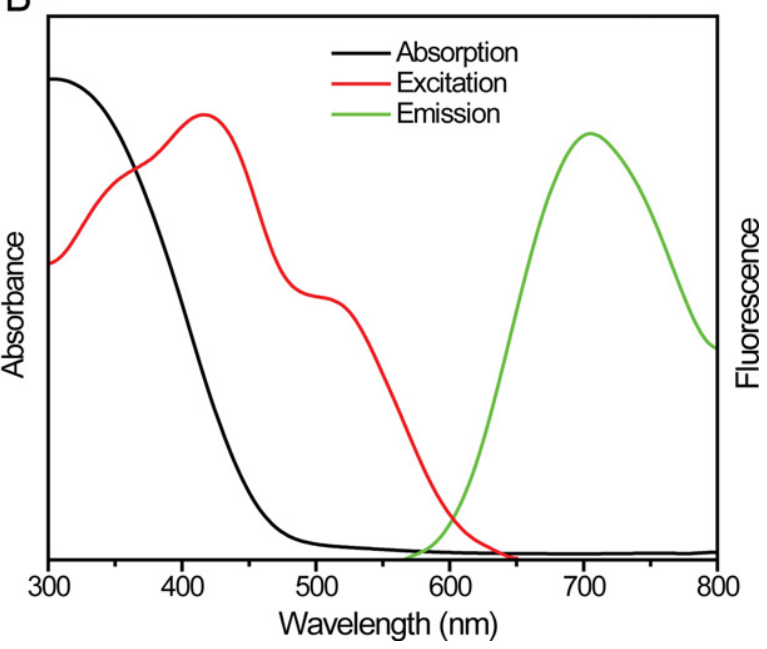

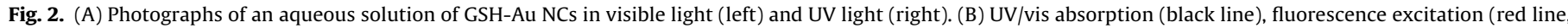
emission at $710 \mathrm{~nm}$ ) and emission (green line, excitation at $410 \mathrm{~nm}$ ) spectra of GSH-Au NCs.
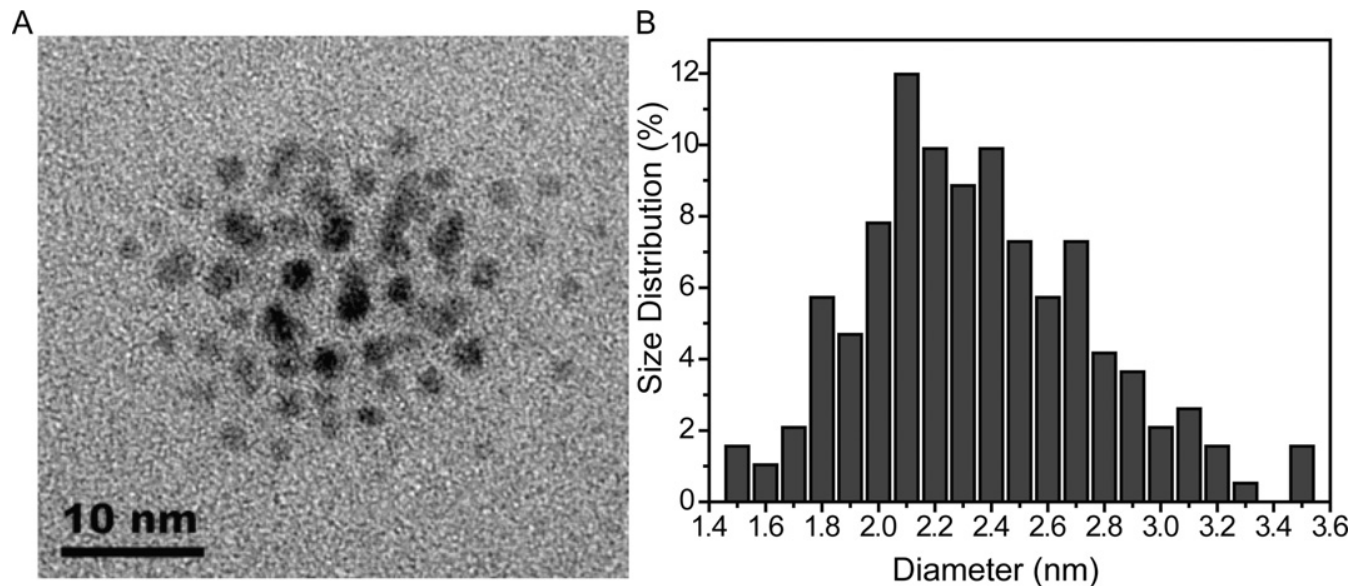

Fig. 3. (A) Typical TEM image of GSH-Au NCs. (B) Corresponding particle size distribution histograms for GSH-Au NCs based on 200 nanoparticles. 


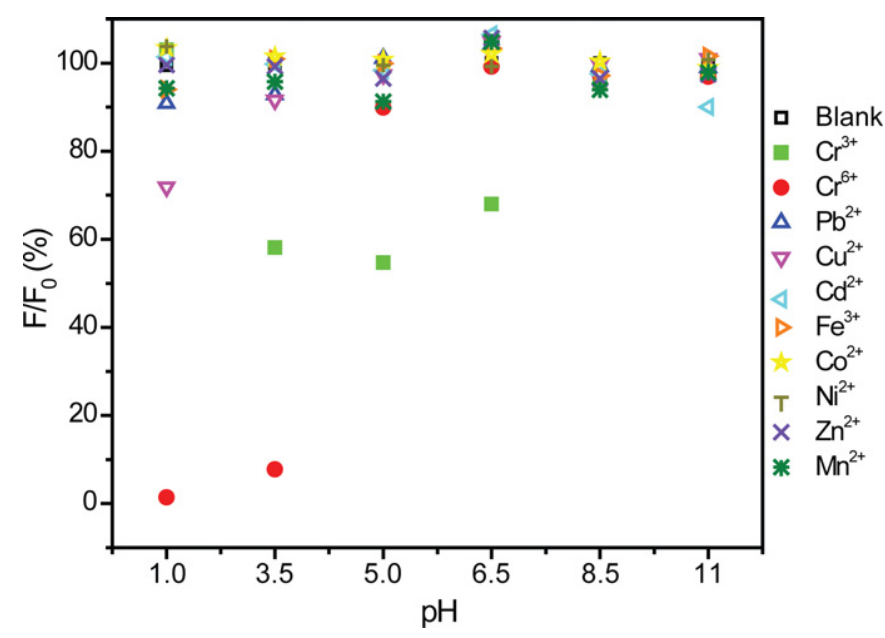

Fig. 4. Effect of pH on the relative fluorescence $\left(F / F_{0}\right)$ of GSH-Au NCs in the absence and presence of $25 \mu \mathrm{M}$ of different metal ions with EDTA.

The color of the as-prepared Au NCs solution was yellow under visible light and bright orange-red under UV light (Fig. 2(A)), indicating that highly luminescent species were formed. A typical absorption spectrum of the prepared GSH-Au NCs solution is shown in Fig. 2(B) (black line). Unlike the UV-vis absorption spectra of gold nanoparticles with diameter over $10 \mathrm{~nm}$, the surface plasmon resonance absorption around $500 \mathrm{~nm}$ is lacking, indicating that the diameter of the prepared material was less than $10 \mathrm{~nm}$. The maximal excitation and emission wavelengths of the as-prepared $\mathrm{Au}$ NCs were 410 and $710 \mathrm{~nm}$, respectively (Fig. 2(B)). Such GSH-Au NCs have a large Stokes shift of $300 \mathrm{~nm}$, which can avoid crosstalk between the excitation and emission signals. To further confirm the formation of GSH-Au NCs, high resolution transmission electron microscopy (HRTEM) images were obtained (Fig. 3(A)). The gold clusters are spherical in shape and well dispersed. Fig. 3(B) shows the distribution of sizes of the gold clusters (average diameter $2.4 \pm 0.7 \mathrm{~nm}$ ).

The quantum yield of luminescent GSH-Au NCs in aqueous solution ( $\mathrm{pH} 7.0$ ) was measured at $1.5 \pm 0.4 \%$, using Rhodamine $6 \mathrm{G}(\mathrm{QY}=0.95$ in ethanol) as the reference. This quantum yield is approximately four times higher than that of the GSH-Au NCs synthesized by reduction with $\mathrm{NaBH}_{4}$ [27]. The as-prepared GSH-Au $\mathrm{NCs}$ in $0.1 \mathrm{M}$ Tris- $\mathrm{HCl}$ solution were stable for over 1 month, and no obvious change of the absorption and emission spectra was observed for over a week (Fig. S2). Furthermore, the high water solubility of GSH-Au NCs allows their application in aqueous media without using organic co-solvents.

\subsection{Effect of $\mathrm{pH}$ values on $\mathrm{Cr}(\mathrm{III})$ and $\mathrm{Cr}(\mathrm{VI})$ detection}

The $\mathrm{pH}$ is a critical parameter in selective determination of $\mathrm{Cr}$ (III) and $\mathrm{Cr}(\mathrm{VI})$. Results given in Fig. 4 indicated that $\mathrm{pH}$ had little effect on the fluorescence quenching of GSH-Au NCs in the presence of EDTA and most metal ions with the exception of $\mathrm{Cr}(\mathrm{III})$ and $\mathrm{Cr}(\mathrm{VI})$ under acidic conditions. While at the higher pH range of 8.5-11, most metal ions including $\mathrm{Cr}(\mathrm{III})$ and $\mathrm{Cr}(\mathrm{VI})$ were unstable and could not react with GSH-Au NCs. Thus, the fluorescence intensity of gold nanoclusters did not change.

At the pH range of $3.5-6.5,25 \mu \mathrm{M}$ of $\mathrm{Cr}$ (III) ions could lead to $32-45 \%$ fluorescence quenching of $2.5 \mathrm{mM}$ GSH-Aunching of $2.5 \mathrm{mM}$ GSH-Au NCs (Fig. 4). The possible reasons were hypothesized as (1) under acidic condition, the $\mathrm{Cr}(\mathrm{III})$ is able to form complex with glutathione (Au NCs-GSH-Cr(III)-GSH-Au NCs) [28], resulting in the aggregation of gold clusters; (2) GSH can bind to $\mathrm{Cr}(\mathrm{III})$ via the terminal glycine group $(\mathrm{N}, \mathrm{O})$ and the deprotonated

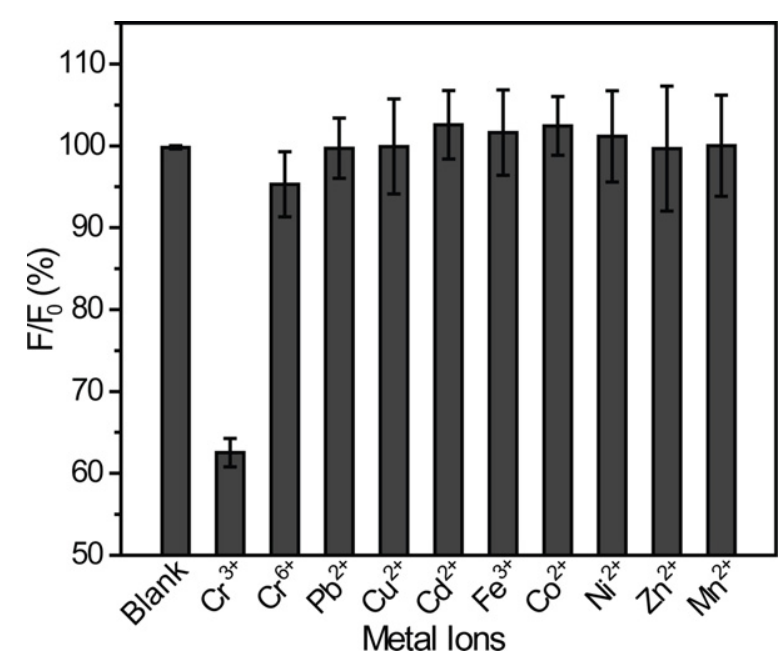

Fig. 5. Effect of $25 \mu \mathrm{M}$ of different metal ions on the relative fluorescence $\left(F / F_{0}\right)$ of GSH-Au NCs at pH 6.5. $F_{0}$ and $F$ correspond to the fluorescence intensity of GSH$\mathrm{Au}$ NCs in the absence and presence of $25 \mu \mathrm{M}$ of different metal ions with EDTA $\left(\lambda_{\mathrm{ex}}=410 \mathrm{~nm}, \lambda_{\mathrm{em}}=710 \mathrm{~nm}\right)$.

sulphur of cysteine $[18,19]$, which may compete with $\mathrm{Au}-\mathrm{S}$ and result in the displacement of GSH from the surface of the gold clusters. The displacement of GSH capping consequently created imperfection on the material surface, thus resulting in fluorescence quenching [29].

Under acidic condition, $\mathrm{Cr}(\mathrm{VI})$ could also lead to fluorescence quenching of GSH-Au NCs (Fig. 4). The reason may be associated with the high positive redox potential of $\mathrm{Cr}(\mathrm{VI})$ at acidic pHs [30]. The redox interaction between $\mathrm{Cr}(\mathrm{VI})$ and GSH $[20,21]$ results in the instability of Au NCs, which ultimately induce fluorescence quenching. More importantly, the fluorescence quenching capability of $\mathrm{Cr}(\mathrm{VI})$ for GSH-Au NCs was highly dependent on pHs. As shown in Fig. 4, $25 \mu \mathrm{M} \mathrm{Cr}(\mathrm{VI})$ resulted in 99\% fluorescence quenching of GSHAu NCs at pH 1.0 and $92 \%$ at $\mathrm{pH} 3.5$. However, it could only cause $10 \%$ fluorescence quenching at $\mathrm{pH} 5.0$ and less than $5 \%$ at $\mathrm{pH} 6.5$. This could be explained by the weaker oxidation capacity of $\mathrm{Cr}(\mathrm{VI})$ at elevated $\mathrm{pHs}[3,30]$. The lower oxidizing power of $\mathrm{Cr}(\mathrm{VI})$ weakened the redox reaction between $\mathrm{Cr}(\mathrm{VI})$ and $\mathrm{GSH}$ which reduced fluorescence quenching of GSH-Au NCs.

Based on the results mentioned above, a stepwise strategy was designed to selectively detect $\mathrm{Cr}(\mathrm{III})$ and $\mathrm{Cr}(\mathrm{VI})$ in water samples (Fig. 1). $\mathrm{Cr}$ (III) was directly detected at pH 6.5 in which $\mathrm{Cr}(\mathrm{VI})$ nearly showed no fluorescence quenching capability for Au NCs. Detection of $\mathrm{Cr}(\mathrm{VI})$ was based on the difference of its relative fluorescence intensities between $\mathrm{pH} 3.5$ and 5.0 in which no interferences from $\mathrm{Cr}$ (III) was observed because the fluorescence quenching capability of $\mathrm{Cr}(\mathrm{III})$ at those two $\mathrm{pH}$ values are at similar levels.

\subsection{Effect of EDTA}

Besides $\mathrm{Cr}(\mathrm{III})$ and $\mathrm{Cr}(\mathrm{VI})$, other metal ions present in natural water system such as $\mathrm{Pb}(\mathrm{II}), \mathrm{Cu}(\mathrm{II}), \mathrm{Co}$ (II) and $\mathrm{Ni}$ (II) could also cause fluorescence quenching of GSH-Au NCs and the potential interactions between those metals and GSH [29] might interfere with the accurate detection of $\mathrm{Cr}(\mathrm{III})$ and $\mathrm{Cr}(\mathrm{VI})$. Therefore, EDTA was added as masking ligand to improve the selectivity of the method for $\mathrm{Cr}(\mathrm{III})$ and $\mathrm{Cr}(\mathrm{VI})$ analysis. Upon addition of EDTA, the interference from other metal ions was notably reduced (Fig. S3). This may be owing to the relatively slower formation kinetics of $\mathrm{Cr}$ (EDTA) complex which have much weaker quenching effect on GSH-Au NCs [31]. The fluorescence quenching capabilities of various heavy metal ions in the presence of different amount of EDTA were further studied. The results indicated with the addition of EDTA, the fluorescence 


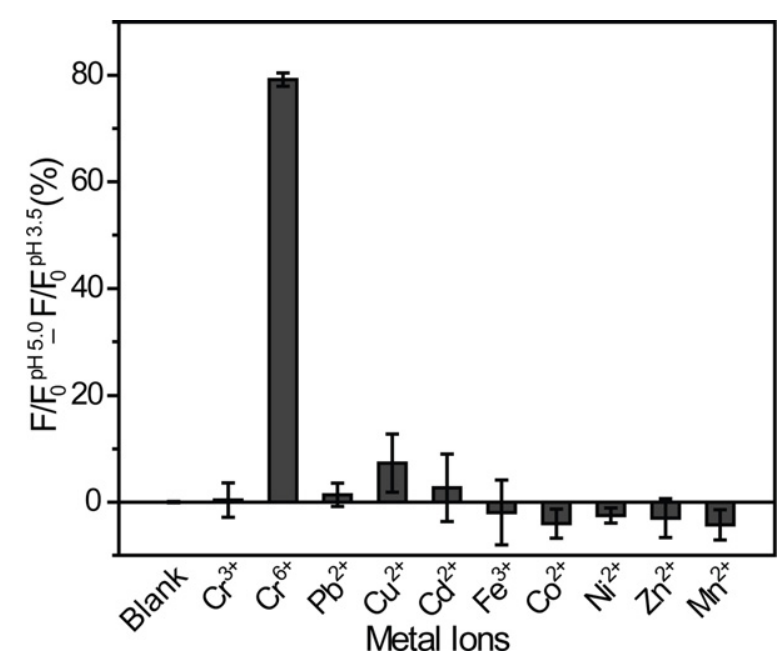

Fig. 6. $F / F_{0(\mathrm{pH} 5.0)}-F / F_{0(\mathrm{pH} 3.5)}$ values in the absence and presence of $25 \mu \mathrm{M}$ of different metal ions with $\operatorname{EDTA}\left(\lambda_{\mathrm{ex}}=410 \mathrm{~nm}, \lambda_{\mathrm{em}}=710 \mathrm{~nm}\right)$.

quenching of GSH-Au NCs introduced by $\mathrm{Pb}(\mathrm{II}), \mathrm{Cu}(\mathrm{II}), \mathrm{Co}(\mathrm{II})$ and $\mathrm{Ni}(\mathrm{II})$ were decreased and $1.25 \mathrm{mM}$ EDTA was appropriate for eliminating the interferences of these metal ions at concentrations up to $25 \mu \mathrm{M}$ (Fig. S3).

\subsection{Selectivity}

The selectivity of the GSH-Au NCs toward $\mathrm{Cr}(\mathrm{III})$ and $\mathrm{Cr}(\mathrm{VI})$ ions was investigated in detail using above strategy. The changes of relative fluorescence intensity $\left(F / F_{0}\right)$ of GSH-Au NCs occurred within $30 \mathrm{~min}$ (Fig. S4). $F_{0}$ and $F$ are the fluorescence intensities of the Au NCs before and after adding metal ions, respectively. As shown in Fig. 5, at pH 6.5, addition of $25 \mu \mathrm{M}$ of $\mathrm{Cr}$ (III) caused approximately $38 \%$ fluorescence quenching of GSH-Au NCs ( $2.5 \mathrm{mM})$ whereas ads $(2.5 \mathrm{mM})$ whereas addition of other metal ions including $\mathrm{Cr}(\mathrm{VI})$ at the same concentration $(25 \mu \mathrm{M})$ led to less than $5 \%$ change, which demonstrated little interference to the fluorescence intensity of $\mathrm{GSH}-\mathrm{Au} \mathrm{NCs}$. The results indicated that GSH-Au NCs at pH 6.5 could be a selective fluorescence probe for $\mathrm{Cr}(\mathrm{III})$ ions.

In the $\mathrm{Cr}(\mathrm{VI})$ determination, $\mathrm{pH} 3.5$ and $\mathrm{pH} 5.0$ was selected as working pHs. As shown in Fig. 6, other metal ions such as $\mathrm{Cr}(\mathrm{III})$, $\mathrm{Pb}(\mathrm{II}), \mathrm{Cu}(\mathrm{II}), \mathrm{Cd}(\mathrm{II}), \mathrm{Fe}(\mathrm{III}), \mathrm{Co}(\mathrm{II}), \mathrm{Ni}(\mathrm{II}), \mathrm{Zn}(\mathrm{II})$ and $\mathrm{Mn}(\mathrm{II})$ at the concentration of $25 \mu \mathrm{M}$ did not cause strong change in the values of $F / F_{0(\mathrm{pH}}$.0) $-F / F_{0(\mathrm{pH} 3.5)}$. Only $25 \mu \mathrm{M}$ of $\mathrm{Cr}(\mathrm{VI})$ ions led to almost $80 \%$ quenching difference of GSH-Au NCs fluorescence between $\mathrm{pH} 3.5$ and $\mathrm{pH}$ 5.0. These results indicate that this system display high selectivity toward $\mathrm{Cr}(\mathrm{VI})$ ions.

\subsection{Analytical performance}

To study the linearity of the method, the value of $F / F_{0}$ was monitored with a series of $\mathrm{Cr}$ (III) solutions. As observed in Fig. 7(A), F/F of gold nanoclusters decreased linearly $\left(R^{2}: 0.9907\right)$ with increasing concentration of $\mathrm{Cr}$ (III) within $25-3800 \mu \mathrm{g} \mathrm{L}^{-1}$ (Fig. 7(B)). When $\mathrm{Cr}$ (III) concentration reached $13 \mathrm{mg} \mathrm{L}^{-1}$, the GSH-Au NCs fluorescence was almost completely quenched.

Furthermore, $\mathrm{Cr}(\mathrm{VI})$ was also investigated with different concentrations added to GSH-Au NCs solutions at $\mathrm{pH} 3.5$ and 5.0. $F / F_{0}$ of GSH-Au NCs decreased with increasing concentration of $\mathrm{Cr}(\mathrm{VI})$ at $\mathrm{pH} 3.5$ (Fig. 8(A)), but no significant changes were found at $\mathrm{pH}$ 5.0 (Fig. 8(B)). Fig. 8(C) shows the corresponding $F / F_{0}$ of GSH-Au $\mathrm{NCs}$ at $\mathrm{pH} 3.5$ and 5.0. From Fig. 8(D), it can be seen that the value of $F / F_{0}(\mathrm{pH} 5.0)-F / F_{0}(\mathrm{pH} 3.5)$ shows a good linearity $\left(R^{2}: 0.9911\right)$ with $\mathrm{Cr}(\mathrm{VI})$ concentration within the range of $5-500 \mu \mathrm{g} \mathrm{L}^{-1}$.

According to Figs. 7(B) and 8(D), the quenching behavior of the fluorescent sensors for $\mathrm{Cr}(\mathrm{III})$ and $\mathrm{Cr}(\mathrm{VI})$ in the tested concentration of $25-13,000 \mu \mathrm{g} \mathrm{L}^{-1}$ and $5-1300 \mu \mathrm{g} \mathrm{L}^{-1}$ all fitted the square root function of $y=b+a \sqrt{x}$ [32]. Therefore, the function was used to further evaluate the performance of the method. Results showed that the function worked very well for both target ions, which simplified the calibration process and widened the detection concentration range (as shown in Table 1 ).

The limit of detection (LOD) was estimated as the lowest concentration of the analyte that could be detected. The lowest detectable response was equal 3 times of the standard deviation (SD) of 7 parallel blank measurements [33]. The solution of GSH-Au NCs $(2.5 \mathrm{mM})$ in the absence of metal ions was used as a blank. The SD of the blank responses was 0.15 for $\mathrm{Cr}$ (III) and 0.05 for $\mathrm{Cr}(\mathrm{VI})$. LODs of $\mathrm{Cr}(\mathrm{III})$ and $\mathrm{Cr}(\mathrm{VI})$ were $2.5 \mu \mathrm{g} \mathrm{L}^{-1}$ and $0.5 \mu \mathrm{g} \mathrm{L}^{-1}$, respectively (Table 1$)$. The reproducibility of the method was also evaluated and the results were satisfactory (as listed in Table 1). The relative standard deviations $(n=5)$ for $\mathrm{Cr}(\mathrm{III})$ and $\mathrm{Cr}(\mathrm{VI})$ were $3.9 \%$ and $2.8 \%$ for run-to-run assays, respectively. The satisfactory day-today RSDs, as listed in Table 1, also indicate the good stability of the GSH-Au NCs.

This method could be considered as environmentally friendly for the use of minute amount of gold nanoclusters, and compared to some fluorimetry and colorimetry methods [33-35] shown in Table 2, it gives comparable or even superior LODs and wider detection range. Compared with other methods such as ETAAS [4,5],
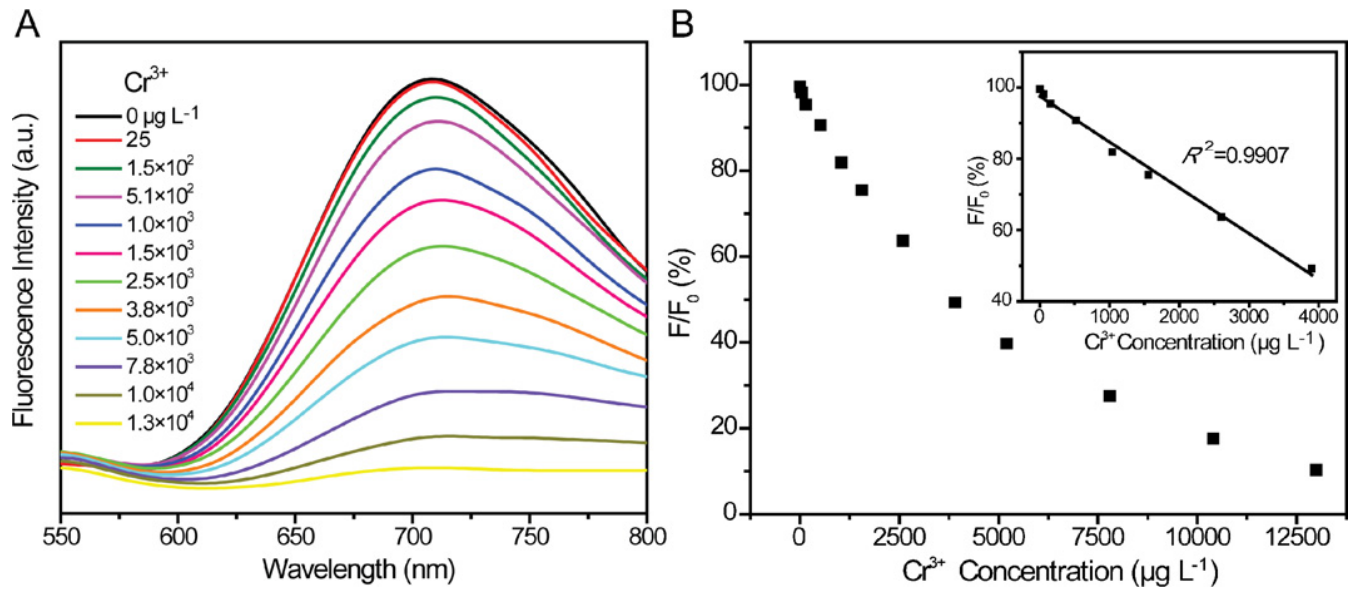

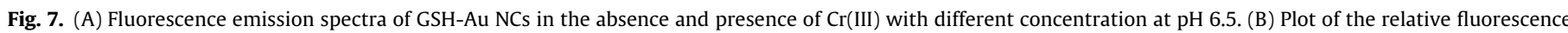
$\left(F / F_{0}\right)$ of GSH-Au NCs versus $\mathrm{Cr}(\mathrm{III})$ concentration. The inset shows the linear detection range for $25-3800 \mu \mathrm{gL}^{-1} \mathrm{of} \mathrm{Cr}(\mathrm{III})\left(\lambda_{\mathrm{ex}}=410 \mathrm{~nm}, \lambda_{\mathrm{em}}=710 \mathrm{~nm}\right)$. 

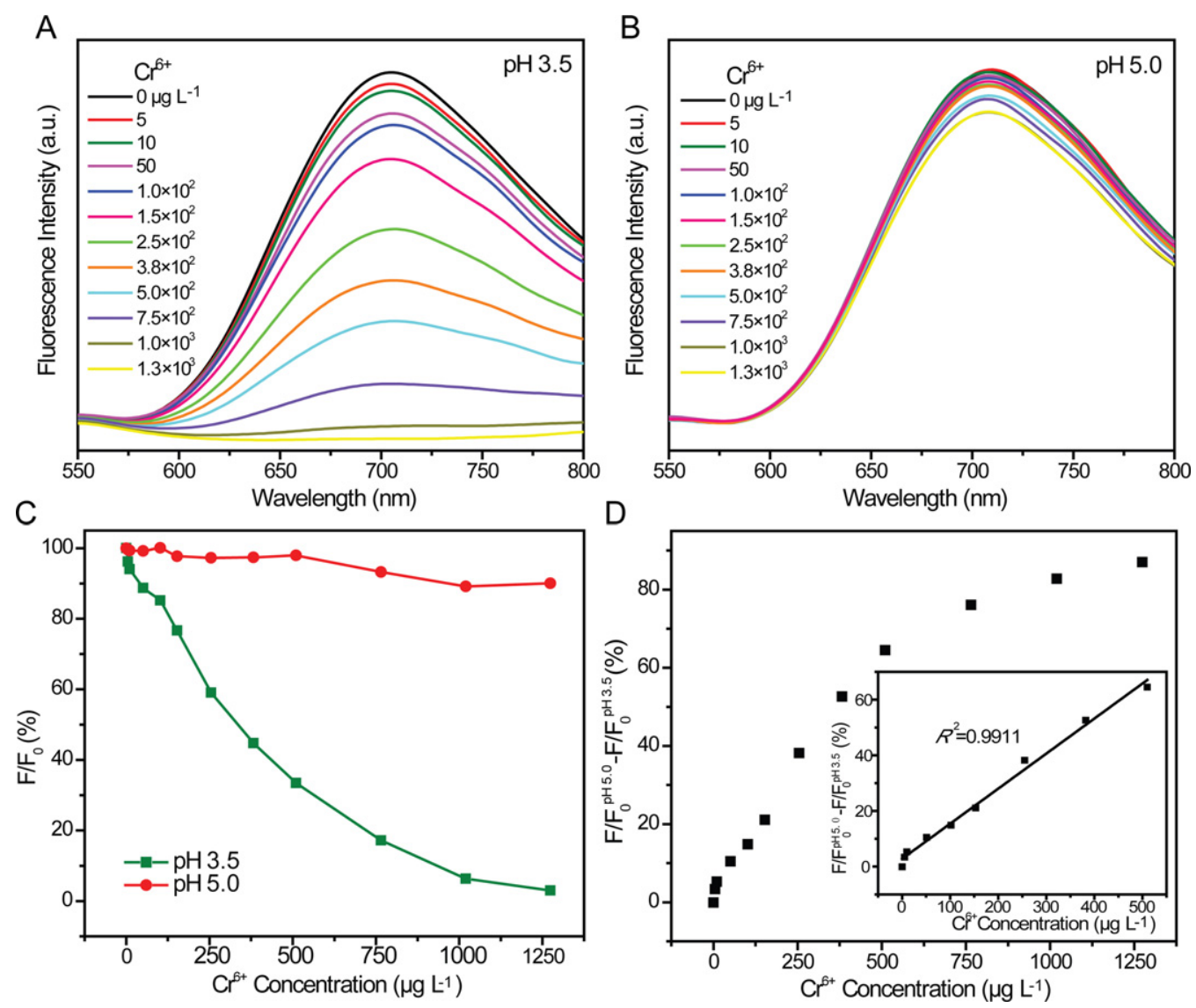

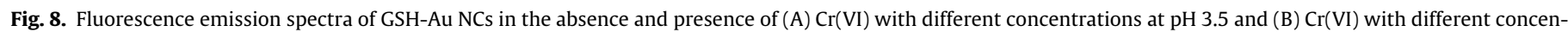

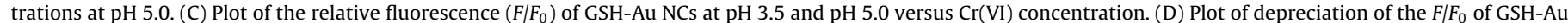
NCs between pH 3.5 and pH 5.0 versus $\mathrm{Cr}(\mathrm{VI})$ concentrations. The inset shows the linear detection range for $5-500 \mu \mathrm{g} \mathrm{L}-1$ of $\mathrm{Cr}(\mathrm{VI})\left(\lambda_{\mathrm{ex}}=410 \mathrm{~nm}, \lambda_{\mathrm{em}}=710 \mathrm{~nm}\right)$.

Table 1

Analytical performance of the method for $\mathrm{Cr}(\mathrm{III})$ and $\mathrm{Cr}(\mathrm{VI})$ detection using GSH-Au NCs under the optimum condition.

\begin{tabular}{|c|c|c|c|c|c|c|c|}
\hline \multirow[t]{2}{*}{ Analyte } & \multirow[t]{2}{*}{ Regression equation } & \multirow[t]{2}{*}{$R^{2 \mathrm{c}}$} & \multirow{2}{*}{$\begin{array}{l}\text { Linear range } \\
\left(\mu \mathrm{gL}^{-1}\right)\end{array}$} & \multirow[t]{2}{*}{$\operatorname{LOD}^{\mathrm{d}}\left(\mu \mathrm{g} \mathrm{L}^{-1}\right)$} & \multicolumn{3}{|l|}{ RSD (\%) } \\
\hline & & & & & Run-to-run ${ }^{\mathrm{e}}$ & Day-to-day $^{\mathrm{f}}$ & Batch-to-batch ${ }^{g}$ \\
\hline $\operatorname{Cr}(\mathrm{III})$ & $\begin{array}{l}y=97.4-0.0128 x^{\mathrm{a} 1} \\
y=106.9-0.874 \sqrt{x}^{\mathrm{a} 2}\end{array}$ & 0.99070 .9908 & $\begin{array}{l}25-3800 \\
25-13000\end{array}$ & 2.5 & 3.9 & 7.5 & 12.2 \\
\hline $\mathrm{Cr}(\mathrm{VI})$ & $\begin{array}{l}y=2.82 \pm 0.126 x^{\mathrm{b} 1} \\
y=-6.55 \pm 2.80 \sqrt{x}^{\mathrm{b} 2}\end{array}$ & 0.99110 .9738 & $\begin{array}{l}5-500 \\
5-1300\end{array}$ & 0.5 & 2.8 & 9.6 & 13.7 \\
\hline
\end{tabular}

a1: linear regression; a2: square root regression. $y=$ relative fluorescence intensity $\left(F / F_{0}\right), x=$ concentration of $\mathrm{Cr}(\mathrm{III})(\mu \mathrm{g} \mathrm{L}-1)$.

b1: linear regression; b2: square root regression. $y=$ the depreciation of $F / F_{0}$ at $\mathrm{pH} 3.5$ and $\mathrm{pH} 5.0, x=\operatorname{concentration}$ of $\mathrm{Cr}(\mathrm{VI})(\mu \mathrm{g} \mathrm{L}-1)$.

c The coefficient of determination $\left(R^{2}\right)$.

d Limit of detection.

e The run-to-run RSDs calculated from five parallel analyses.

f The day-to-day RSDs calculated between 3 days with five parallel analyses per day.

$\mathrm{g}$ The batch-to-batch RSDs determined form three batches of GSH-Au NCs.

Table 2

Comparison of the method with some other studies on detection of $\mathrm{Cr}(\mathrm{III})$ and $\mathrm{Cr}(\mathrm{VI})$.

\begin{tabular}{|c|c|c|c|c|c|}
\hline \multirow[t]{2}{*}{ Detection technique } & \multirow[t]{2}{*}{ Sample treatment } & \multirow[t]{2}{*}{ Target ions } & \multicolumn{2}{|c|}{ Detection limit (detection range) $\left(\mu \mathrm{g} \mathrm{L}^{-1}\right)$} & \multirow[t]{2}{*}{ Ref. } \\
\hline & & & $\mathrm{Cr}(\mathrm{III})$ & $\mathrm{Cr}(\mathrm{VI})$ & \\
\hline ETAAS/ICP-MS & $\begin{array}{l}\text { On-line solid phase extraction with } \\
\text { two minicolumns }\end{array}$ & $\mathrm{Cr}(\mathrm{VI})$ & - & $0.003(0.01-1)$ & {$[4]$} \\
\hline ETAAS & $\begin{array}{l}\text { Adsorption of } \mathrm{Cr}(\mathrm{III}) \text { with iron } \\
\text { phosphate }\end{array}$ & $\mathrm{Cr}(\mathrm{III})$ & $0.02(0.05-2.5)$ & - & [5] \\
\hline ICP-OES & Triton X-114 and CPB-Triton X-114 & $\mathrm{Cr}(\mathrm{III}) / \mathrm{Cr}(\mathrm{VI})$ & $0.02(5-1500)$ & $0.05(10-1000)$ & [9] \\
\hline ICP-OES & Magnetic solid phase extraction & $\mathrm{Cr}(\mathrm{III}) / \mathrm{Cu}(\mathrm{II}) / \mathrm{Pb}(\mathrm{II}) / \mathrm{Zn}$ (II) & $0.035(0.1-100)$ & - & [10] \\
\hline ICP-MS & $\begin{array}{l}\text { Chelating and anionic ion-exchange } \\
\text { minicolumns }\end{array}$ & $\mathrm{Cr}(\mathrm{III}) / \mathrm{Cr}(\mathrm{VI})$ & $0.03(0.3-60)$ & $0.009(0.1-60)$ & [11] \\
\hline Fluorimetry & $\mathrm{N}$-amyl alcohol & $\mathrm{Cr}(\mathrm{VI})$ & - & $0.47(5.2-104)$ & [33] \\
\hline Fluorimetry & DPC & $\mathrm{Cr}(\mathrm{VI})$ & - & $1.2(3.6-520)$ & [34] \\
\hline Colorimetry & - & $\mathrm{Cr}(\mathrm{III})$ & 52 & - & [35] \\
\hline Fluorimetry & EDTA & $\mathrm{Cr}(\mathrm{III}) / \mathrm{Cr}(\mathrm{VI})$ & $2.5(25-13000)$ & $0.5(5-1300)$ & This study \\
\hline
\end{tabular}


Table 3

Spike recoveries of chromium ions in water samples $(n=3)$ under the optimum condition.

\begin{tabular}{|c|c|c|c|c|c|c|}
\hline \multirow[t]{2}{*}{ Analyte } & \multicolumn{3}{|c|}{ Tap water samples } & \multicolumn{3}{|c|}{ Effluent water samples } \\
\hline & Added $\left(\mu \mathrm{g} \mathrm{L}^{-1}\right)$ & Found $\left(\mu g \mathrm{~L}^{-1}\right)$ & $\overline{\text { Recovery (\%) }}$ & $\overline{\text { Added }\left(\mu g \mathrm{~L}^{-1}\right)}$ & Found $\left(\mu \mathrm{g} \mathrm{L}^{-1}\right)$ & Recovery (\%) \\
\hline \multirow[t]{3}{*}{$\mathrm{Cr}(\mathrm{III})$} & 0 & $\mathrm{ND}^{\mathrm{a}}$ & & 0 & ND & \\
\hline & 510 & $509 \pm 18^{b}$ & $99.8 \pm 3.5^{c}$ & 510 & $388 \pm 14$ & $76.3 \pm 2.7$ \\
\hline & 2500 & $2862 \pm 259$ & $114 \pm 10$ & 2500 & $2900 \pm 318$ & $116 \pm 13$ \\
\hline \multirow[t]{3}{*}{$\mathrm{Cr}(\mathrm{VI})$} & 0 & ND & & 0 & ND & \\
\hline & 25 & $21 \pm 2$ & $89.3 \pm 6.5$ & 25 & $18 \pm 2$ & $77.7 \pm 8.3$ \\
\hline & 250 & $216 \pm 13$ & $86.7 \pm 5.2$ & 250 & $194 \pm 16$ & $78.1 \pm 6.4$ \\
\hline
\end{tabular}

a Non-detectable.

b Mean \pm standard deviation.

ICP-OES [9,10], and ICP-MS [11], this method could be considered more economical and the sample treatments are more simple. Additionally, the use of a 96-well plate instead of a colorimetric cuvette made the detection procedure simple, fast and high throughput.

\subsection{Analysis of $\mathrm{Cr}(\mathrm{III})$ and $\mathrm{Cr}(\mathrm{VI})$ in real water samples}

The method was applied to real water samples spiked with $\mathrm{Cr}(\mathrm{III})$ or $\mathrm{Cr}(\mathrm{VI})$ ions. Standard solutions were spiked to tap water or effluent water samples to prepare solutions with $\mathrm{Cr}(\mathrm{III})$ at 510 and $2500 \mu \mathrm{g} \mathrm{L}^{-1}$ or $\mathrm{Cr}(\mathrm{VI})$ at 25 and $250 \mu \mathrm{g} \mathrm{L}^{-1}$. As listed in Table 3, the recoveries ranged $86.7-114 \%$ for tap water samples and $76.3-116 \%$ for the effluent water samples. These recoveries were satisfactory, indicating that the sample matrix caused no significant interference to the detection.

\section{Conclusion}

Fluorescent GSH-Au NCs were synthesized via a facile one-step method. The diameters of the obtained gold clusters were smaller than $3 \mathrm{~nm}$, possessing strong fluorescence with a quantum yield of $\sim 1.5 \%$. Following this, a new method for selective determination of $\mathrm{Cr}(\mathrm{III})$ and $\mathrm{Cr}(\mathrm{VI})$ was developed based on the fluorescence quenching of GSH-Au NCs at different pHs. As compared to other reported methods, the method used in this study offers advantages including simplicity, good selectivity, high sensitivity, wider linear dynamic range and is relatively green and economical. Therefore, this method could have the potential to be a useful tool for selective determination of $\mathrm{Cr}(\mathrm{III})$ and $\mathrm{Cr}(\mathrm{VI})$ in environmental water samples.

\section{Acknowledgments}

We acknowledge the financial support from the National Basic Research Program of China (nos. 2009CB421605 and 2011CB936001), the National Natural Science Foundation of China (nos. 21107120 and 20977096).

\section{Appendix A. Supplementary data}

Supplementary data associated with this article can be found, in the online version, at http://dx.doi.org/10.1016/j.aca.2013.01.042.

\section{References}

[1] V. Gómez, M.P. Callao, TrAC Trends Anal. Chem. 25 (2006) 1006-1015.

[2] R. Rakhunde, L. Deshpande, H.D. Juneja, Crit. Rev. Environ. Sci. Technol. 42 (2012) 776-810

[3] J. Kotaś, Z. Stasicka, Environ. Pollut. 107 (2000) 263-283.

[4] M.L. Chen, Y.N. Zhao, D.W. Zhang, Y. Tian, J.H. Wang, J. Anal. Atom. Spectrom 25 (2010) 1688-1694.

[5] X.X. Zhang, S.S. Tang, M.L. Chen, J.H. Wang, J. Anal. Atom. Spectrom. 27 (2012) 466-472.

[6] M. Hashemi, S.M. Daryanavard, Spectrochim. Acta A: Mol. Biomol. Spectrosc. 92 (2012) 189-193.

[7] J. Ma, B. Yang, R.H. Byrne, J. Hazard. Mater. 219-220 (2012) 247-252.

[8] L.L. Wang, J.Q. Wang, Z.X. Zheng, P. Xiao, J. Hazard. Mater. 177 (2010) 114-118.

[9] N.N. Meeravali, K. Madhavi, S.J. Kumar, J. Anal. Atom. Spectrom. 26 (2011) 214-219.

[10] G. Cheng, M. He, H. Peng, B. Hu, Talanta 88 (2012) 507-515.

[11] M.M.L. Guerrero, E.V. Alonso, J.M.C. Pavon, M.T.S. Cordero, A.G. de Torres, J. Anal. Atom. Spectrom. 27 (2012) 682-688.

[12] L. Shang, S. Dong, G.U. Nienhaus, Nano Today 6 (2011) 401-418.

[13] J. Xie, Y. Zheng, J.Y. Ying, Chem. Commun. 46 (2010) 961-963.

[14] J.A. Annie Ho, H.C. Chang, W.T. Su, Anal. Chem. 84 (2012) 3246-3253.

[15] S. Roy, G. Palui, A. Banerjee, Nanoscale 4 (2012) 2734-2740.

[16] W. Chen, X. Tu, X. Guo, Chem. Commun. (2009) 1736-1738.

[17] Z. Yuan, M. Peng, Y. He, E.S. Yeung, Chem. Commun. 47 (2011) 11981-11983.

[18] A. Levina, L. Zhang, P.A. Lay, Inorg. Chem. 42 (2003) 767-784.

[19] M. Abdullah, J. Barrett, P. O'Brien, J. Chem. Soc., Dalton Transac. (1985) 2085-2089.

[20] H.J. Wiegand, H. Ottenwälder, H.M. Bolt, Toxicology 33 (1984) 341-348.

[21] J. Aiyar, H.J. Berkovits, R.A. Floyd, K.E. Wetterhahn, Environ. Health Perspect. 92 (1991) 53-62.

[22] C. Zhou, M. Long, Y. Qin, X. Sun, J. Zheng, Angew. Chem. Int. Ed. 50 (2011) 3168-3172.

[23] C.T. Chen, W.J. Chen, C.Z. Liu, L.Y. Chang, Y.C. Chen, Chem. Commun. (2009) $7515-7517$.

[24] C. Zhou, C. Sun, M. Yu, Y. Qin, J. Wang, M. Kim, J. Zheng, J. Phys. Chem. C 114 (2010) 7727-7732.

[25] J. Xie, Y. Zheng, J.Y. Ying, J. Am. Chem. Soc. 131 (2009) 888-889.

[26] R.P. Briñas, M. Hu, L. Qian, E.S. Lymar, J.F. Hainfeld, J. Am. Chem. Soc. 130 (2008) 975-982.

[27] S. Link, A. Beeby, S. FitzGerald, M.A. El-Sayed, T.G. Schaaff, R.L. Whetten, J. Phys Chem. B 106 (2002) 3410-3415

[28] M.T. Armas, A. Mederos, P. Gili, S. Dominguez, R. Hernandez-Milina, P. Lorenzo, M.L. Araujo, F. Brito, A. Otero, M.G. Castellanos, Chem. Speciation Bioavailability 16 (2004) 45-52.

[29] X. Wang, Y. Lv, X. Hou, Talanta 84 (2011) 382-386.

[30] E. Nieboer, A.A. Jusys, Biologic chemistry of chromium, in: J.O. Nriagu, E. Niebor (Eds.), Chromium in Natural and Human Environments, Wiley Interscience New York, 1988, pp. 21-81.

[31] W.R. Seitz, W.W. Suydam, D.M. Hercules, Anal. Chem. 44 (1972) 957-963.

[32] A. Hakonen, N. Strömberg, Analyst 137 (2012) 315-321.

[33] M.S. Hosseini, F. Belador, J. Hazard. Mater. 165 (2009) 1062-1067.

[34] H. Chen, J. Ren, Talanta 99 (2012) 404-408.

[35] Z.Y. Sun, Q.L. Zheng, H.B. Li, Chem. J. Chin. Univ.-Chin. 32 (2011) 2219-2222. 